\title{
GROWTH, AND YIELD CHARACTERISTICS AS WELL AS PESTS AND DISEASES SUSCEPTIBILITY OF CHILI PEPPER (Capsicum annuum L.) UNDER DIFFERENT PLANT DENSITIES AND PRUNING LEVELS
}

\author{
Setiawati, W. ${ }^{1}$ - Muharam, A. ${ }^{2}$ - Hasyim, A. ${ }^{1}$ - Prabaningrum, L. ${ }^{1}-$ MotKasan, T. K. ${ }^{1}-$ \\ MURTININGSIH, R. ${ }^{1}-$ LUKMAN, L. ${ }^{3}-$ MEJAYA, M. J. ${ }^{4 *}$ \\ ${ }^{1}$ Indonesian Vegetable Research Institute, Jl. TangkubanParahu No. 517, Lembang Bandung \\ Barat 40391, Indonesia \\ ${ }^{2}$ Indonesian Center for Agricultural Technology Assessment and Development, Indonesia \\ (ICATAD), Jl. Tentara Pelajar No. 10 Bogor 16111, West Java, Indonesia \\ ${ }^{3}$ Directorate General of Horticulture, Ministry of Agriculture, Republic of Indonesi, Jl. AUP no. \\ 3 Pasar Minggu, Jakarta Selatan, Indonesia \\ ${ }^{4}$ Indonesian Legumes and Tuber Crops Research Institute (ILETRI), Jl. Raya Kendakpayak Km. \\ 8 PO Box 66, Malang 65101, East Java, Indonesia \\ Corresponding author \\ e-mail:mmejaya@yahoo.com; phone: +62-341-806-074 \\ (Received $2^{\text {nd }}$ Sep 2021; accepted $23^{\text {rd }}$ Nov 2021)
}

\begin{abstract}
The field experiments were conducted at Indonesian Vegetable Research Institute (IVEGRI) West Java, Indonesia during the period of July 2018 to February 2019. The objective of the study was to determine the effect of three plant densities $\left(20,000,30,000\right.$ and 40,000 plants ha $\left.^{-1}\right)$ and four stem pruning levels (control, 3 stems, 4 stems, and shoot pruning) on growth and yield parameters as well as pest and diseases incidences for chili pepper. Split plot experiment was performed using a randomized block design with three replications. The recommended cultural practices were done for better crop growth and good yields. Results showed no interactions between plant density and pruning for any of the variables measured. Chili pepper growth, yield, and quality and incidence of pest and diseases can be effectively manipulated by plant density and pruning. Increasing of plant population from 20,000 to 30,000 plants ha${ }^{1}$ resulted in the increased of total fruit yield to 52.58\%, however, total fruit yield declined up to $34.09 \%$ at $40,000 \mathrm{plant} / \mathrm{ha}$. Pruning significantly affected fruit yield from 4.65 to $20.33 \%$. Shoot pruning produced higher number of branches, and resulted in maximum yield per $\mathrm{ha}^{-1}$ due to higher number of shoots contributing to the production of more number of fruits. Growing chili pepper at a density of 30,000 plant $\mathrm{ha}^{-1}$ was better than the conventional methods, and it combination with shoot pruning in nurseries could be used as an alternative method to increase the production of chili pepper.
\end{abstract}

Keywords: plant population, branches, susceptibility, fruit quality, production

\section{Introduction}

Chili pepper (Capsicum annuum L.) is one of important spices and vegetable crops in the world. FAOSTAT (2020) reported that world production of chili pepper was 42.282 million tons in both dry and green fruits from 3.718 million hectares of land. Indonesia is currently ranked fourth in chili production after China, Mexico and Turkey and account for about 5 percent of global annual chili production (Kementan, 2020). An average production, however, is low $\left(8.46 \mathrm{t} \mathrm{ha}^{-1}\right)$ compared to its potential yields of 12 to $20 \mathrm{t} \mathrm{ha}^{-1}$. It attributed to a combination of various bottlenecks in production constraints such as climate change, poor cultivation practices, high production costs for 
seeds, fertilizers, and pesticides, as well as high pests and diseases attacks (Setiawati et al., 2021).

Successful of crop production could be affected by various factors including transplanting age, fertilization, pest and diseases management, pruning and plant density. Plant density and plant arrangement influenced plant development, plant dry weight, stem diameter, plant width, growth and marketable yield of chili pepper. Planting density, which can be maintained by adjusting row spacing and plant spacing, is a strong determinant of yield in various crops, including chili pepper.

Yield of sweet pepper was depended on the number of plants accommodated per unit area of land (Maboko and Plooy, 2008; El Naim and Jabereldar, 2010; Islam et al., 2011). Plant density of chili pepper for double population increased production up to $67 \%$, and plant density of 40,000 plants $\mathrm{ha}^{-1}$ increased productivity by $123 \%$ compared to the conventional technology (9,570 plants ha ${ }^{-1}$ ) (Adams et al., 2001; O'Keefe and Palada, 2002). The chili variety used did not affect the productivity. A number of studies have indicated a linear increase in fruit yield when plant density is increased (Jovicich et al., 2003, 2004; Mavengahama et al., 2009) and then declined as plant population increased up to a point (Akintoye, 2009; Mavengahama et al., 2009).

Chili pepper plants have a branching habit, therefore, fruit development is controlled by restricting the branching pattern to $1,2,3$ and 4 main branches (Alsadon et al., 2013). The reasons for pruning sweet pepper are to train plant growth to facilitate light penetration throughout the leaf canopy for more efficient interception of light (Jovicich et al., 2004). Pinching of marigold plants resulted in an increased number of branches per plant (Chauhan et al., 2005). Pruning to two or three stems was reported to be effective in increasing yield and reducing fruit size of cherry tomatoes to a more acceptable marketable size (Dasgan and Abak, 2003). Chili pepper plants are commonly infested by numerous insect pests that attack at its various growth stages. Plant density and pruning had a significant effect on the presence of pests. Plant density and pruning are very important for the optimization of plant spacing per unit area (El Naim et al., 2010). Many factors influence the optimum plant population for a crop such as availability of water, nutrients and sunlight, length of growing season, potential plant size, and the plant's capacity to change its form in response to varying environmental conditions (morphological plasticity). By determining optimum plant population under suitable environment, it is possible to get optimum yield.

Majority of the chili growers in Indonesia have little knowledge about the advantage of pruning in chili production. Usually the farmers of Indonesia cultivate chili without pruning and even they do not maintain proper plant density and plant population. Populations vary from 15000 to 20000 plants ha ${ }^{-1}$. The objective of this study was to evaluate the effect of different plant density and pruning systems on the growth and yield characteristics as well as the pest and diseases susceptibility for chili pepper in open field condition.

\section{Methodology}

\section{Place and time of study}

The study was conducted in the research field station of the Indonesian Vegetables Research Institutes (IVEGRI), Lembang, Bandung, West Java Province, Indonesia from July 2018 to February 2019. This site is $1,250 \mathrm{~m}$ above sea level and located at $60^{\circ} 30^{\prime} \mathrm{S}$ and $-107^{\circ} 30^{\prime} \mathrm{E}$. Soil type in this location is mainly Andisol with the average $\mathrm{pH}$ of 5.0 
- 6.0. This area experiences average temperature of $19-24^{\circ} \mathrm{C}$, humidity ranges from $34-$ $90 \%$ and average rainfall of $2,207 \mathrm{~mm} /$ year.

\section{Research design}

A complete randomized block with split-plot arrangement and three replications was established up to achieve the goal. The main plot was population density (a) consisting of (a1) 20,000 plants ha $\mathrm{h}^{-1}$ (one plant per hole), (a2) 30,000 plants ha $\mathrm{h}^{-1}$ (one and two plants per hole), and (a3) 40,000 plants ha ${ }^{-1}$ (two plants per hole). The pruning system was applied as subplot, and there were four subplots set up in the field i.e. (b1) control or upruned plants, (b2) three branches remaining after pruning, (b3) four branches remaining after pruning, and (b4) shoot pruning or pinching.

The chili pepper variety of Kencana was used in the experiment. Seedlings were raised in the protected nursery to minimize pests and diseases attacks. Seedling pruning for shoot pruning treatment were conducted in the nursery. Three weeks old seedlings were pruned using sterile scissor right under the first leaf shoots. Two weeks after pruning, seedlings were transplanted in to the field as per experiment layout (Figure 1). As for other treatments i.e., b2, and b3, five weeks old seedlings were transplanted in to the field and pruned at the base of main stem on the 30 days after transplanting (DAT) to follow the treatments.

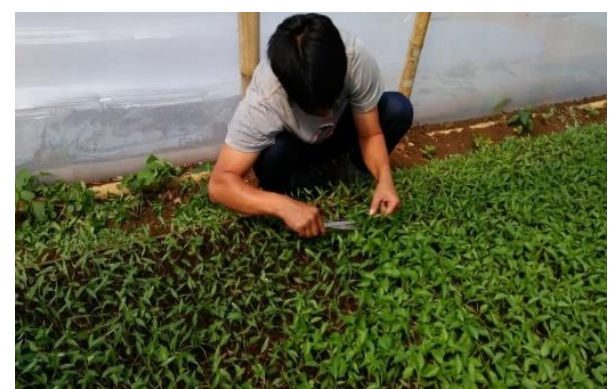

a) Shoot pruning

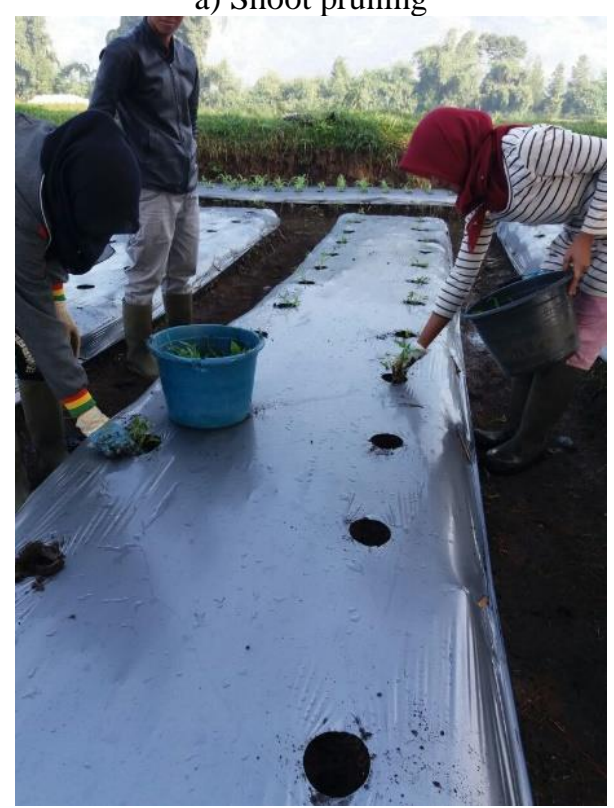

c) Zigzag transplanting system

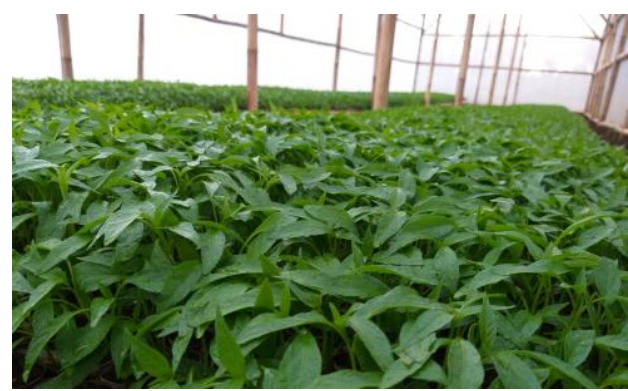

b) Chili seedlings ready to be transplanted

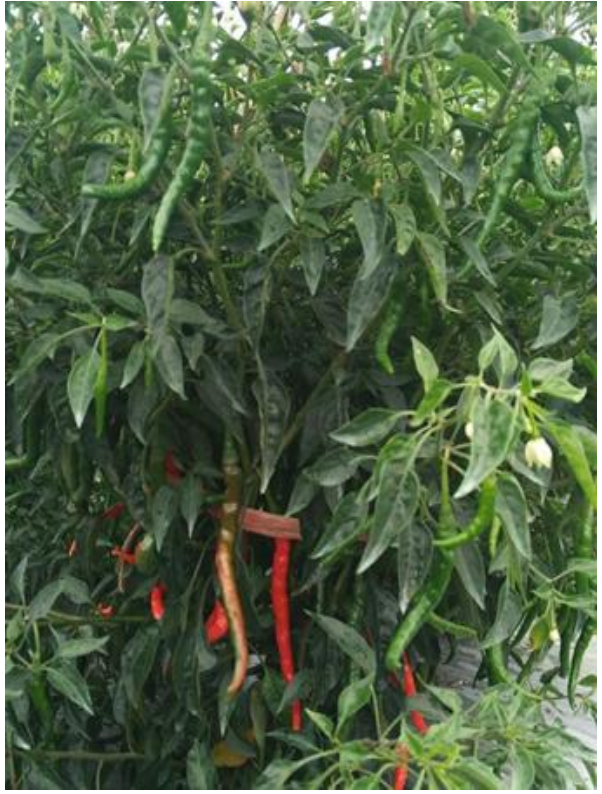

d) shoot pruning crop performance on 90 DAT

Figure 1. Shoot pruning treatment 
An area of $88 \mathrm{~m} \times 136 \mathrm{~m}$ was divided into three equal blocks. There were 36 plots altogether in the experiment. The size of each plot was $13 \mathrm{~m} \mathrm{x} 14 \mathrm{~m}$ (700 plants per plot) and the plots were arranged in spacing $50 \mathrm{~cm} \times 70 \mathrm{~cm}$ in a zigzag system to avoid competition in light, distribution of roots and nutrients contents The distance within blocks and plots were $1 \mathrm{~m}$ and $0.5 \mathrm{~m}$, respectively. Organic materials consisting of mature compost were applied as a basal fertilizer along with NPK composite fertilizers. The dose of organic materials and NPK was $30 \mathrm{t} \mathrm{ha}^{-1}$ and $1 \mathrm{t} \mathrm{ha}^{-1}$, respectively. The chemical characteristics of Andisol soil and mature compost are presented on Tables 1 and 2 , respectively.

Tabel 1. Chemical characteristics of Andisol soil

\begin{tabular}{c|c|c}
\hline Chemical characteristics* & Analysis values & Criteria \\
\hline $\mathrm{pH}\left(\mathrm{H}_{2} \mathrm{O}\right)$ & 5.80 & Acid \\
$\mathrm{pH}(\mathrm{KCl})$ & 4.70 & Acid \\
$\mathrm{C}-$ rganik $(\%)$ & 5.80 & Very high \\
$\mathrm{N}-$ total $(\%)$ & 0.72 & High \\
$\mathrm{C} / \mathrm{N}$ & 9.0 & Low \\
$\mathrm{P}_{2} \mathrm{O}_{5}-$ Bray $1(\mathrm{ppm})$ & 3.50 & Very low \\
$\mathrm{K}-\mathrm{Morgan}(\mathrm{ppm})$ & 135.50 & Medium \\
$\mathrm{Ca}(\mathrm{cmol}(+) / \mathrm{kg})$ & 2.80 & Low \\
$\mathrm{Mg}(\mathrm{cmol}(+) / \mathrm{kg})$ & 0.27 & Very low \\
\hline
\end{tabular}

*IVEGRI's Integrated Testing Laboratory (2018)

Table 2. Chemical characteristics of mature compost

\begin{tabular}{c|c}
\hline Chemical characteristics & $\begin{array}{c}\text { Mature compost (made of enrichment stable manure + } \\
\text { plant residues compost) }\end{array}$ \\
\hline $\mathrm{pH}\left(\mathrm{H}_{2} \mathrm{O}\right)$ & 7.67 \\
$\mathrm{pH}(\mathrm{KCl})$ & 7.31 \\
Kadar air (\%) & 48.46 \\
$\mathrm{C}$-organik (\%) & 10.71 \\
$\mathrm{~N}$-total (\%) & 0.57 \\
$\mathrm{C} / \mathrm{N}$ & 19.0 \\
$\mathrm{P}_{2} \mathrm{O}_{5}(\%)$ & 0.58 \\
$\mathrm{~K}_{2} \mathrm{O}(\%)$ & 0.45 \\
$\mathrm{CaO}(\%)$ & 0.71 \\
$\mathrm{MgO}(\%)$ & 0.26 \\
$\mathrm{Fe}(\mathrm{ppm})$ & 8878.0 \\
$\mathrm{Mn}(\mathrm{ppm})$ & 423.0 \\
$\mathrm{Cu}(\mathrm{ppm})$ & 32.0 \\
$\mathrm{Zn}(\mathrm{ppm})$ & 55.0 \\
$\mathrm{~Pb}(\mathrm{ppm})$ & 20.09 \\
\hline
\end{tabular}

*IVEGRI’s Integrated Testing Laboratory (2018)

The beds were covered with silvery plastic mulch. The land was cleared manually started with plugging and making beds.

\section{Data analysis}

Growth of plant and percentage of plant damage due to pests and diseases attack were recorded. Ten sample plants from each plot were randomly selected in each 
observation day. Assessments were conducted throughout the growing season in weekly interval started from 30 Days After Planting (DAP).

Plant damage due to thrips was measured using to follow Equation 1 formula as follow:

$$
I=\frac{\sum(n \times v)}{N \times z} \times 100 \%
$$

Notes:

I, damage levels (\%)

$\mathrm{v}$, the value of damage category

$\mathrm{n}$, number of plants that have same $\mathrm{v}$ value

$\mathrm{Z}$, the value of highest damage category

$\mathrm{N}$, number of observed plants

Category of plant damage value (v) is determined based on the percentage of leaf area damage i.e.:

0 , if there is no damage leaf area

1 , if there is $>0-\leq 20 \%$ leaf area damage

3 , if there is $>20-\leq 40 \%$ leaf area damage

5 , if there is $>40-\leq 60 \%$ leaf area damage

7 , if there is $>60-\leq 80 \%$ leaf area damage

9 , if there is $>80-\leq 100 \%$ leaf area damage.

The incidence of anthracnose was observed from total harvested fruit. The intensity of anthracnose attack on chili fruit was measured using Equation 2 as follow:

$$
\text { Disease incidence }=\frac{\sum \text { infected fruits }}{\sum \text { observed fruits }} \times 100 \%
$$

Yield assessment: Data collected were fruit length $(\mathrm{cm})$, fruit diameter $(\mathrm{cm})$, individual fruit weight $(\mathrm{g})$. Chili pepper fruit per plot were weighed for each treatment to observe the total yield. Data are presented as expected weight $\mathrm{t} \mathrm{ha}^{-1}$. The percent increase in yield over control in various treatments was calculated to follow Equation 3.

$$
\% \text { of increasing yield }=\frac{\text { yield in treatment-yield in control }}{y \text { ield } \text { in control }} \times 100 \%
$$

\section{Statistical analysis}

The data were subjected to two ways ANOVA (SAS Program). Significantly different means $(\mathrm{P}<0.05)$ were separated using Duncan Multiple Range Test (DMRT) at $5 \%$ probability. Count data were transformed by square root of $(x+0.5)$, and transformation of percentage data by arcsine-square root.

\section{Results and Discussion}

There was no significant interaction between plant density and pruning for all parameter observed $(\mathrm{p} \geq 0.05)$, showing that these factors took action independently on variables of plant height, number of flowers per plant, fruit length, fruit diameter, number of fruits per plant, individual fruit weight, pest and diseases, and chili yield. 


\section{Vegetative growth parameters}

Plant density and pruning system gave significant effects on chili plant height $(\mathrm{p} \leq 0.05)$. The plant height ranged between 63.03 and $71.41 \mathrm{~cm}$. Plant height increased linearly in response to increased plant densities at all observations (Table 3). This was due to intra-specific competition for the sunlight (El Naim, 2010; Edgar et al., 2017). Plant height showed significant variation at different days after transplanting (DAT) due to pruning. At 93 DAT the maximum plant height $(69.34 \mathrm{~cm})$ was obtained from (b3) which was statistically similar to b0 and b1, while the minimum $(65.30 \mathrm{~cm})$ was recorded from (b4). This was probably caused to the fact that competition between plants for available water, nutrients and light was less in one branch system than in 3 or 4 branches systems. Shoots pruning/pinching (b4) significantly reduced the plant height in comparison with the other treatments. Decreased plant height and increased number of branches could reduce vertical plant growth, resulting in translocation of photosynthates to leaf axils, hence increased number of axillary (Kumar et al., 2014; Singh et al., 2015; Setiawati et al., 2021).

Table 3. The average of plant height on chili pepper at different treatments

\begin{tabular}{|c|c|c|c|c|c|c|c|c|c|c|}
\hline \multirow{2}{*}{ Treatments } & \multicolumn{10}{|c|}{ (Plant height at plant ages) .......... (DAP) } \\
\hline & 30 & 37 & 44 & 51 & 58 & 65 & 72 & 79 & 86 & 93 \\
\hline \multicolumn{11}{|c|}{ Population density } \\
\hline a1.20,000 plants ha ${ }^{-1}$ & $10.02^{\mathrm{b}}$ & $12.96 b$ & $16.43 b$ & $19.81 \mathrm{c}$ & $26.71 \mathrm{c}$ & $34.18 \mathrm{c}$ & $43.03 c$ & $51.64 \mathrm{c}$ & $57.46 \mathrm{c}$ & $63.03 \mathrm{~b}$ \\
\hline a2.30,000 plants ha $^{-1}$ & $11.18^{\mathrm{a}}$ & $13.98 b$ & $17.92 \mathrm{ab}$ & $22.76 b$ & $29.48 b$ & $38.12 b$ & $47.90 \mathrm{~b}$ & $57.11 b$ & $62.45 b$ & $69.25 \mathrm{a}$ \\
\hline a3.4,000 plants ha $^{-1}$ & $12.20^{\mathrm{a}}$ & $15.69 a$ & $19.31 \mathrm{a}$ & $25.15 \mathrm{a}$ & $34.82 \mathrm{a}$ & $43.87 \mathrm{a}$ & $53.82 \mathrm{c}$ & $60.58 \mathrm{a}$ & $65.82 \mathrm{a}$ & $71.41 \mathrm{a}$ \\
\hline LSD $5 \%$ & 1.05 & 1.46 & 1.95 & 1.84 & 2.63 & 2.96 & 3.16 & 2.34 & 2.36 & 2.53 \\
\hline \multicolumn{11}{|c|}{$\begin{array}{l}\text { Pruning system } \\
\end{array}$} \\
\hline $\begin{array}{l}\text { b1. Control (upruned } \\
\text { plants) }\end{array}$ & $11.63 \mathrm{a}$ & $14.73 \mathrm{a}$ & $18.00 \mathrm{a}$ & $23.19 \mathrm{a}$ & $31.73 \mathrm{a}$ & $39.70 \mathrm{a}$ & $49.22 \mathrm{a}$ & $56.92 \mathrm{a}$ & $61.71 \mathrm{ab}$ & $69.29 \mathrm{a}$ \\
\hline $\begin{array}{l}\text { b2. Three branches } \\
\text { remaining }\end{array}$ & $11.87 \mathrm{a}$ & $14.51 \mathrm{a}$ & $18.71 \mathrm{a}$ & $23.39 \mathrm{a}$ & $30.82 \mathrm{a}$ & $39.56 \mathrm{a}$ & $49.16 \mathrm{a}$ & $57.04 \mathrm{a}$ & $62.42 \mathrm{ab}$ & $67.90 \mathrm{ab}$ \\
\hline $\begin{array}{l}\text { b3. Four branches } \\
\text { remaining }\end{array}$ & $11.09 \mathrm{a}$ & $16.57 \mathrm{a}$ & $20.5 \mathrm{a}$ & $25.38 \mathrm{a}$ & $33.11 \mathrm{a}$ & $41.81 \mathrm{a}$ & $50.96 a$ & $58.09 \mathrm{a}$ & $63.90 \mathrm{a}$ & $69.34 \mathrm{a}$ \\
\hline b4. Shoot pruning & $9.21 \mathrm{~b}$ & $12.47 \mathrm{~b}$ & $15.41 b$ & $19.80 \mathrm{~b}$ & $27.08 \mathrm{~b}$ & $35.33 b$ & $45.37 \mathrm{~b}$ & $54.20 \mathrm{~b}$ & $60.16 b$ & $65.30 \mathrm{~b}$ \\
\hline LSD $5 \%$ & 1.21 & 1.69 & 2.26 & 2.13 & 3.04 & 3.42 & 3.65 & 2.70 & 2.73 & 2.92 \\
\hline
\end{tabular}

Means followed by the same letter in the column are not significantly different according to Duncan's Multiple Range Test at $\alpha=0.05$

\section{Pests and diseases incidence on chili pepper}

The lowest plant damage occurred in plant density of 20,000 plants $\mathrm{ha}^{-1}$, followed by density of 30,000 and 40,000 plants $\mathrm{ha}^{-1}$. In the pruning treatment, the lowest plant damage occurred in shoot pruning (b4), followed by b1, b2 and highest was presented in b3. There was no significant effect of plant density on the plant damage in most of observation days. However, on the 44 until 93 DAP plant damage due to thrips attack in the 40,000 plants $\mathrm{ha}^{-1}$ plot were significantly higher compared to other treatments (Table 4). Other studies suggested that there might be an inverse relationship between the attack rates and the number of branches. Shivute (2005) reported that pruned tomatoes were less prone to pest attack than those, which were not pruned. 
Tabel 4. Plant damage (\%) due to thrips attack

\begin{tabular}{|c|c|c|c|c|c|c|c|c|c|c|}
\hline \multirow{2}{*}{ Treatments } & \multicolumn{10}{|c|}{ Plant damage (\%) at DAP } \\
\hline & 30 & 37 & 44 & 51 & 58 & 65 & 72 & 79 & 86 & 93 \\
\hline \multicolumn{11}{|c|}{ Populations density } \\
\hline a1. 20,000 plants ha-1 & 0.00 & $1.48 \mathrm{a}$ & $1.02 \mathrm{ab}$ & $2.50 \mathrm{a}$ & $6.02 \mathrm{~b}$ & $7.32 \mathrm{~b}$ & $6.39 \mathrm{a}$ & $12.96 \mathrm{a}$ & $5.83 \mathrm{a}$ & $4.54 \mathrm{a}$ \\
\hline a2. 30,000 plants ha- & 0.00 & $1.57 \mathrm{a}$ & $0.83 b$ & $3.24 \mathrm{a}$ & $7.13 \mathrm{ab}$ & $8.33 \mathrm{~b}$ & $6.39 \mathrm{a}$ & $12.59 \mathrm{a}$ & $4.72 \mathrm{a}$ & $4.91 \mathrm{a}$ \\
\hline a3. 40,000 plants ha $^{-1}$ & 0.00 & $0.93 \mathrm{a}$ & $1.94 \mathrm{a}$ & $2.50 \mathrm{a}$ & $9.28 \mathrm{a}$ & $11.39 \mathrm{a}$ & $6.21 \mathrm{a}$ & $13.24 \mathrm{a}$ & $4.81 \mathrm{a}$ & $4.81 \mathrm{a}$ \\
\hline \multicolumn{11}{|c|}{ Pruning system } \\
\hline $\begin{array}{l}\text { b1.Control (upruned } \\
\text { plants) }\end{array}$ & 0.0 & $1.23 \mathrm{a}$ & $0.99 \mathrm{a}$ & $2.47 \mathrm{a}$ & $6.67 b c$ & $9.88 \mathrm{a}$ & $6.42 \mathrm{a}$ & $12.84 \mathrm{a}$ & $4.57 \mathrm{~b}$ & $4.69 \mathrm{ab}$ \\
\hline $\begin{array}{l}\text { b2. Three branches } \\
\text { remaining }\end{array}$ & 0.0 & $0.99 a$ & $1.11 \mathrm{a}$ & $3.21 \mathrm{a}$ & $8.15 \mathrm{ab}$ & 8.64ab & $6.05 \mathrm{a}$ & $13.09 \mathrm{a}$ & $4.94 a b$ & $4.20 \mathrm{~b}$ \\
\hline $\begin{array}{l}\text { b3. Four branches } \\
\text { remaining }\end{array}$ & 0.0 & $3.21 \mathrm{a}$ & $2.22 \mathrm{a}$ & $3.33 \mathrm{a}$ & $9.88 \mathrm{a}$ & $11.48 \mathrm{a}$ & $6.67 \mathrm{a}$ & $13.83 \mathrm{a}$ & $6.05 \mathrm{a}$ & $5.43 \mathrm{a}$ \\
\hline b4. Shoot pruning & 0.0 & $0.86 \mathrm{a}$ & $1.11 \mathrm{a}$ & $1.97 \mathrm{a}$ & $5.21 \mathrm{c}$ & $6.05 \mathrm{~b}$ & $6.30 \mathrm{a}$ & $12.22 \mathrm{a}$ & $4.94 \mathrm{ab}$ & $4.32 \mathrm{~b}$ \\
\hline
\end{tabular}

Means followed by the same letter in the column are not significantly different according to Duncan's Multiple Range Test at $\alpha=0.05$

Plant density and pruning had a significant effect on incidence of anthracnose diseases. Plant density of 20,000 plants $\mathrm{ha}^{-1}$ and pruning (b1 and b4) had decreased the incidence of this diseases compared to the other treatments (Table 5). Pruning made the sunlight freely illuminates the parts of plants and the leaves more productive in carbohydrates production, this situation provides benefits to the plant because it could reduce the infestation level of pests and diseases (Setiawati et al., 2021).

Table 5. Effects of populations density and pruning on total yields incidence of Anthracnose diseases on fruit of chili pepper

\begin{tabular}{|c|c|c|c|}
\hline Treatments & $\begin{array}{l}\text { Total fruit yield } \\
\qquad\left(\mathbf{t ~ h a}^{-1}\right)\end{array}$ & $\%$ Increasing yield & $\begin{array}{c}\text { \% Incidence of } \\
\begin{array}{c}\text { Anthracnose diseases on } \\
\text { fruit }\end{array} \\
\end{array}$ \\
\hline \multicolumn{4}{|c|}{ Populations density } \\
\hline a1. 20,000 plants ha ${ }^{-1}$ & $12.38^{\mathrm{c}}$ & - & $37.17^{\mathrm{b}}$ \\
\hline a2. 30,000 plants $\mathrm{ha}^{-1}$ & $18.89^{\mathrm{a}}$ & 52.58 & $37.29^{b}$ \\
\hline a3. 40,000 plants ha ${ }^{-1}$ & $16.60^{b}$ & 34.09 & $38.82 \mathrm{a}$ \\
\hline \multicolumn{4}{|c|}{ Pruning system } \\
\hline $\begin{array}{l}\text { b1.Control (upruned } \\
\text { plant) }\end{array}$ & $15.05^{b}$ & - & $37.97^{\mathrm{a}}$ \\
\hline $\begin{array}{l}\text { b2. Three branches } \\
\text { remaining }\end{array}$ & $16.01^{\mathrm{b}}$ & 6.38 & $35.77^{\mathrm{c}}$ \\
\hline $\begin{array}{l}\text { b3. Four branches } \\
\text { remaining }\end{array}$ & $15.75^{b}$ & 4.65 & $37.97^{\mathrm{a}}$ \\
\hline b4. Shoot pruning & $18.11^{\mathrm{a}}$ & 20.33 & $35.90^{b}$ \\
\hline
\end{tabular}

Means followed by the same letter in the column are not significantly different according to Duncan's Multiple Range Test at $\alpha=0.05$

\section{Physical fruit characteristics}

Number of fruits plant ${ }^{-1}$ and number flower plant ${ }^{-1}$ increased significantly with the increase of plant density. Different plant densities showed significant variation on number of fruits plant ${ }^{-1}$ and number flower plant ${ }^{-1}$. The highest number of fruits plant ${ }^{-1}$ 
and number flower plant ${ }^{-1}$ was found from a 2 which was followed by a 3 and the lowest number was found for a1. This is a direct effect of plant competition. Green pepper fruit number and weight per hectare increased as plant population as well (Buler and Mika, 2009).

Different levels of pruning showed significant variation on fruits plant ${ }^{-1}$ and number flower plant ${ }^{-1}$. The highest number of fruits plant ${ }^{-1}$ and number flower plant ${ }^{-1}$ (445.45) was observed for b4 which was followed by b2 (406.24), b3 (405.04) and the lowest number (381.02) was found for b1 (no stem pruning) (Table 6). Number of fruits per plant affected by pruning (Thakur et al., 2005). Fruit size parameters such as weight, length and diameter fruit of chili were affected by pruning as well. An influence on a number of tree physiological processes connected with the growth, yield and quality of fruits (Buler and Mika, 2009). Pruning decreased total yield, yield plant $^{-1}$, plant weight and number of fruits plant ${ }^{-1}$, but it increased fruit weight. Branch numbers plant ${ }^{-1}$ ranged from 11.27 to 14.37 , by which significant differences in branch numbers plant $^{-1}$ occurred between the plant density of 20,000 plants $^{-1} \mathrm{a}^{-1}$ and two others $(30,000$ and 40,000 plants $\mathrm{ha}^{-1}$ ). Generally, an increase in plant densities led to significantly lower branching. Low density resulted in an increased number of branches plant ${ }^{-1}$. This was consistent with the findings of Islam et al. (2011) who reported that there is a relationship between the number of branches and plant population density. The denser the plant population, the less the number of branches produced and will delay the flowering time of plants (Karuppaiah and Krishna, 2005; Mane et al., 2006). Generally, increasing the plant population increased competition among plants for soil moisture, nutrient, light and carbon dioxide (El Naim and Jabereldar, 2010).

Table 6. Yield components of chili pepper

\begin{tabular}{|c|c|c|c|c|c|c|}
\hline Treatments & $\begin{array}{c}\text { Branch } \\
\text { number / } \\
\text { Plant }\end{array}$ & $\begin{array}{c}\text { Flower } \\
\text { number / } \\
\text { Plant }\end{array}$ & $\begin{array}{c}\text { Fruit number / } \\
\text { Plant }\end{array}$ & $\begin{array}{l}\text { Fruit length } \\
\qquad(\mathrm{cm})\end{array}$ & $\begin{array}{l}\text { Fruit weight } \\
\text { (g) }\end{array}$ & $\begin{array}{c}\text { Fruit } \\
\text { diameter } \\
(\mathbf{c m})\end{array}$ \\
\hline \multicolumn{7}{|c|}{ Populations density } \\
\hline $\begin{array}{l}\text { a1. 20,000 plants } \\
\text { ha }^{-1}\end{array}$ & $14.37^{\mathrm{a}}$ & $151.43^{\mathrm{b}}$ & $216.02^{\mathrm{b}}$ & $13.10^{\mathrm{a}}$ & $5.04^{\mathrm{a}}$ & $0.85^{\mathrm{a}}$ \\
\hline $\begin{array}{l}\text { a2. 30,000 plants } \\
\text { ha }^{-1}\end{array}$ & $11.42^{\mathrm{b}}$ & $166.75^{\mathrm{ab}}$ & $278.63^{\mathrm{a}}$ & $13.42^{\mathrm{a}}$ & $4.97^{\mathrm{a}}$ & $0.83^{a}$ \\
\hline $\begin{array}{c}\text { a3. 40,00 plants } \\
\mathrm{ha}^{-1}\end{array}$ & $11.27^{\mathrm{b}}$ & $180.37^{\mathrm{a}}$ & $235.12^{\mathrm{b}}$ & $13.32^{\mathrm{a}}$ & $5.10^{a}$ & $0.83^{\mathrm{a}}$ \\
\hline \multicolumn{7}{|c|}{ Pruning system } \\
\hline $\begin{array}{c}\text { b1. Control } \\
\text { (upruned plants) }\end{array}$ & $12.31^{\mathrm{a}}$ & $150.31^{\mathrm{b}}$ & $230.71^{b}$ & $12.85^{b}$ & $4.86^{b}$ & $0.80^{b}$ \\
\hline $\begin{array}{l}\text { b2. Three branches } \\
\text { remaining }\end{array}$ & $12.62^{\mathrm{a}}$ & $163.53^{\mathrm{ab}}$ & $242.71^{\mathrm{ab}}$ & $13.51^{\mathrm{a}}$ & $5.16^{a}$ & $0.85^{a}$ \\
\hline $\begin{array}{l}\text { b3. Four branches } \\
\text { remaining }\end{array}$ & $12.13^{\mathrm{a}}$ & $171.51^{\mathrm{a}}$ & $233.53^{b}$ & $13.48^{\mathrm{a}}$ & $5.03^{\mathrm{ab}}$ & $0.84^{\mathrm{a}}$ \\
\hline b4. Shoot pruning & $12.33^{\mathrm{a}}$ & $179.38^{\mathrm{a}}$ & $266.07^{\mathrm{a}}$ & $13.29^{\mathrm{a}}$ & $5.10^{\mathrm{ab}}$ & $0.82^{\mathrm{a}}$ \\
\hline
\end{tabular}

Means followed by the same letter in the column are not significantly different according to Duncan's Multiple Range Test at $\alpha=0.05$

\section{Yield characteristics}

Yield increase as plant density increased (Table 5). The highest total yield obtained was $18.89 \mathrm{t} \mathrm{ha}^{-1}$ from the second highest plant density $\left(30,000\right.$ plants ha $\left.{ }^{-1}\right)$ and 18.11 
$\mathrm{t} \mathrm{ha}^{-1}$ from shoots pruning in nursery while the lowest yield per hectare $\left(12.38 \mathrm{t} \mathrm{ha}^{-1}\right)$ was recorder at density 20,000 plants $\mathrm{ha}^{-1}$. Increasing plant densities resulted in a greater yield of hot chili pepper and bell pepper (Jovicich et al., 2004), and "Spanish" pepper, Jalapeno chili peppers and other plants (Russo, 2003; Jovicich et al., 2003; Khasmakhi-Sabet et al., 2009; Mavengahama et al., 2009).

This was probably due to the increasing in the number of plants per unit area, which might contribute to the production of extra yield per unit area leading to the high yield. However, as plant population was increased to 40,000 plants $\mathrm{ha}^{-1}$, total fruit yield was decreased up to $34.09 \%$. The production per plant doubled when one and two plants per hole left (30,000 plant ha $\left.{ }^{-1}\right)$ compared with two plants per hole $\left(40,000\right.$ plant ha $\left.^{-1}\right)$. This shows that the yield per plant lost when was two plants were left per hole was offset by another plant in the same hole.

Yield per unit area tends to increase as plant density increase up to a point and then declines (Akintoye et al., 2009), however, Aminifard et al. (2010) reported that yield per unit area tends to increase as plant density increase. This may be due to better availability of nutrients and better translocation of photosynthesis, such as competition for various environmental resources, availability of water, nutrients and sunlight (Mavengahama, 2009). Plant population increased from 20,000 up to 30,000 plants/ha, total fruit yield was also increased to $52.58 \%$, however, yield declined up to $34.09 \%$ at $40,000 \mathrm{plant} / \mathrm{ha}$. Pruning significantly affected fruit yield from 4.65 to $20.33 \%$. Shoot pruning produced more number of branches resulted in maximum yield per ha due to more number of shoots contributed in producing more number of fruits. Planting chili pepper at plant density of 30,000 plant/ ha was an optimum plant density which was better than the two others (20,000 and 40,000 plants ha $\left.{ }^{-1}\right)$. Plant density of 30,000 plant/ ha and together with shoot pruning in nurseries increased total fruit yield productivity of chili pepper.

\section{Conclusions}

Chili pepper growth, yield and quality, as well as the pest and diseases incidence can be effectively managed through plant density and pruning manipulation. The fruit yield can be increased up to $52.58 \%$ by adding plant population from 20,000 up to 30,000 plants/ha. However, adding plant population up to 40,000 plant ha ${ }^{-1}$ reduced $34.09 \%$ of yield. Pruning could significantly improve yield from 4.65 to $20.33 \%$. Shoot pruning can add more branches on the plant and consequently more fruits can be produced to eventually resulting maximum yield $\mathrm{ha}^{-1}$. The plant density of 30,000 plant ha ${ }^{-1}$ with zigzag transplanting system and shoot pruning/pinching in nursery application was considered as powerful method to boost higher productivity and quality. Therefore, this pruning technology practice could be recommended to chili farmers to obtain higher marketable yield in chili pepper. There is further research needed to determine the upper limit for plant population, particularly on the basis of economic viability.

Acknowledgments. We deeply thank to Prof. Dr. B.M. Shepard (Professor Emeritus at Clemson University, South Carolina, United State) who gave comments and corrected English grammar of the manuscripts. 


\section{REFERENCES}

[1] Adams, H. V., Lauckner, F. B., Sisnett, D. D. (2001): Effects of high plant population densities on yields, plant and fruit characters of the hot pepper cultivar, West Indies Red. - Proceedings of the Caribbean Food Crop Society 37: 197-201.

[2] Akintoye, H. A., Kintomo, A. A., Adekunle, A. A. (2009): Yield and fruit quality of watermelon in response to plant population. - International Journal of Vegetable Science 15: 369-380.

[3] Alsadon, A., Wahb-Allah, M., Abdel-Razzak, H., Ibrahim, A. (2013): Effects of pruning systems on growth, fruit yield and quality traits of three greenhouse-grown bell pepper (Capsicum annuum L.) cultivars. - Australian Journal of Crop Science 7(9): 1309-1316.

[4] Aminifard, M. H., Aroiee, H., Karimpour, S., Nemati, H. (2010): Growth and Yield Characteristics of paprika pepper (Capsicum annuum L.) in response to plant density. Asian Journal of Plant Sciences 9(5): 276-280.

[5] Buler, Z., Mika, A. (2009): The influence of canopy architecture on light interception and distribution in 'Samion' apple trees. - Journal of Fruit and Ornamental Plant Research 17(2): 45-52.

[6] Chauhan, S., Singh, C. N., Singh, A. K. (2005): Effect of vermicompost and pinching on growth and flowering in marigold cv. Pusa Narangi Gainda. - Progressive Horticulture 37(2): 419-422.

[7] Dasgan, H. Y., Abak, K. (2003): Effects of plant density and number of shoot on yield and fruit characteristics of peppers grown in glasshouses. - Turkish Journal of Agricultural Forestry 27: 29-35.

[8] Edgar, O. N., Gweyi-Onyango, J. P., Korir, N. K. (2017): Plant Row Spacing Effect on Growth and Yield of Green Pepper (Capsicum annuum L.) in Western Kenya. - Archives of Current Research International 7(3): 1-9.

[9] El Naim, A. M., Jabereldar, A. A. (2010): Effect of Plant density and Cultivar on Growth and Yield of Cowpea (Vigna unguiculata L. Walp). - Australian Journal of Basic and Applied Sciences 4(8): 3148-3153.

[10] El Naim, A. M., Eldouma, M. A., Abdalla, A. E. (2010): Effect of weeding frequencies and plant density on vegetative growth characteristic in groundnut (Arachis hypogaea L.) in North Kordofan of Sudan. - International Journal of Applied Biology and Pharmaceutical Technology 1(3): 1889-1893.

[11] FAOSTAT. (2020): FAOSTAT online. - Rome: United Nations Food and Agriculture Organization. http://faostat.fao.org/default/aspx?lang-en.

[12] Islam, M., Saha, S., Akand, H., Rahim, A. (2010): Effect of spacing on the growth and yield of sweet pepper (Capsicum annuum L.). - Journal of Central European Agriculture 12(2): 328-335.

[13] Jovicich, E., Cantliffe, D. J., Stofella, P. J. (2003): Spanish pepper trellis system and high plant density can increase fruit yield, fruit quality and reduced labour in hydroponic, passive-ventilated greenhouse crop. - Acta Horticulturae (ISHS) 614: 255-262.

[14] Jovicich, E., Cantliffe, D. J., Stofella, P. J. (2004): Fruit yield and quality of greenhousegrown bell pepper as influenced by density, container and trellis system. - Hort. Technology 14: 507-513.

[15] Karuppiah, P., Krishna, G. (2005): Response of spacings and nitrogen levels on growth flowering and yield characters of French marigold (Tagetes patula Linn.). - Journal of Ornamental Horticulture 8(2): 96-99.

[16] Kementan. (2020): Outlook cabai. Komoditas Pertanian Sub Sektor Hortikultura. - Pusat Data dan Sistem Informasi Pertanian. Kementrian Pertanian, 70p. file://C:/Users/USER/Downloads/Outlook\%20Cabai\%20Besar\%202020.pdf.

[17] Khasmakhi-Sabet, A., Sedaghathoor, S., Mohammady, J., Olfati, J. A. (2009): Effect of plant density on bell pepper yield and quality. - International Journal of Vegetable Science 15: 264-271. 
[18] Kumar, R., Sood, S., Sharma, S., Kasana, R. C., Pathania, V. L., Singh, B., Singh, R. D. (2014): Effect of plant spacing and organic mulch on growth, yield and quality of natural sweetener plant Stevia and soil fertility in western Himalayas. - International Journal of Plant Production 8(3): 311-334.

[19] Maboko, M. M., Du Plooy, C. P. (2008): Effect of pruning on yield and quality of hydroponically grown cherry tomato (Lycopersicon esculentum). - South African Journal of Plant and Soil 25(3): 178-181.

[20] Mane, P. K., Bankar, G. H., Makne, S. S. (2006): Effect of spacing, bulb size and depth of planting on growth and bulb production in tuberose (Polianthes tuberosa) cv. Single. Indian Journal of Agricultural Research 40(1): 64-67.

[21] Mavengahama, S., Ogunlela, V. B., Mariga, I. K. (2009): Agronomic performance of paprika (Capsicum annuum L.) in Response to Varying Plant Populations and Arrangement in the Small holder Sector Zimbabwe. - Asian Journal of Crop Science 1(2): 96-104.

[22] O'Keefe, D. A., Palada, M. C. (2002): In-row plant spacing affects growth and yield of four hot pepper cultivars. - Proceedings of the Caribbean Food Crop Society 38: 162-168.

[23] Russo, V. M. (2003): Planting date plant density affect yield of pungent and no pungent Jalapeno peppers. - HortScience 38(4): 520-523.

[24] Setiawati, W., Udiarto, B. K., Hasyim, A. (2021): Manipulation of chili plant architecture to enhance productivity and pests control. - IOP Conference Series: Earth and Environmental Science 752: 012059.

[25] Shivute, B. K. L. (2005): Influence of pruning on tomato production under controlled environments. - Agricultura Tropica Et Subtropica 38(2): 79-81.

[26] Singh, A. K., Singh, S. V., Sisodia, A., Hembrum, R. (2015): Effect of pinching and nitrogen on growth flowering and seed yield of African marigold cv. Pusa Narangi Gainda. - Environmental \& Ecology 33(4B): 1876-1879.

[27] Thakur, M. C., Shyam, L., Arun, J. (2005): Effect of different training systems and spacing on yield and quality characters and its impact on economics of tomato production. - Horticulure Journal 18(1): 64-68. 